\title{
Conferec (Conference CMS)
}

\author{
Sahirul Alim Tri Bawono \\ Fakultas MIPA, Program Studi D3 Teknik Informatika \\ Universitas Negeri Sebelas Maret \\ Email: sahirul@mipa.uns.ac.id \\ Fendi Adi Purnomo \\ Fakultas MIPA, Program Studi D3 Teknik Informatika \\ Universitas Negeri Sebelas Maret \\ Email: fendi_aji@mipa.uns.ac.id \\ Agus Purnomo \\ Fakultas MIPA, Program Studi D3 Teknik Informatika \\ Universitas Negeri Sebelas Maret \\ Email: guspur@mipa.uns.ac.id \\ Rizky Nuzuliati \\ Fakultas MIPA, Program Studi D3 Teknik Informatika \\ Universitas Negeri Sebelas Maret \\ Email: nuzuliatirizky@gmail.com
}

\begin{abstract}
ABSTRAK
Conference merupakan media bagi peneliti untuk saling bertemu pada waktu dan ruang yang sama untuk saling bertukar ilmu berupa publikasi hasil penelitian. Penyelenggaraan website membutuhkan manajemen pendaftaran, proses review dan pembayaran. Website tata kelola conference dibutuhkan untuk mempermudah proses-proses tersebut.

Pembuatan CMS Conference menggunakan MySQL, Apache, PHP, Codeigniter. MySQL adalah program untuk memanajemen database. Apache adalah program untuk melayani proses respon dan request yang ada di Internet. PHP adalah bahasa pemrograman. Codeigniter adalah Framework untuk memudahkan proses pengkodean program.

Hasil yang diperoleh dari penelitian adalah CMS Conference telah berhasil dibuat dengan tidak ditemukan syntax error dan logic error pada program. Fitur utama yang dimiliki yaitu manajemen tampilan conference, manajemen penerimaan artikel, manajemen proses reviewer, menejemen proses penerimaan artikel dan manajemen pembayaran.
\end{abstract}

Kata kunci: Sistem, Conference, Website.

\section{ABSTRACT}

Conference is a medium for researchers to exchange experiences. The organization of the website requires registration management, review and payment process. Web site conference management is required for these processes.

Making CMS Conference using MySQL, Apache, PHP, Codeigniter.MySQL is a program to manage the database. Apache is a program to serve the process of response and demand that is on the internet. PHP is a programming language. Codeigniter is a framework to facilitate the process of coding the program.

Results resulting from this research is CMS Conference has been successfully created with no found syntax error and error logic in the program. The main features are the management of conference display, acceptance management articles, review process management, management of the process of receiving articles and payment management 
Keywords: System, Conference, Website.

\section{PENDAHULUAN}

Conference adalah media berupa tempat dan waktu untuk mempertemukan beberapa orang bertemu dan berdiskusi tentang sesuatu yang menarik. Para peneliti juga memiliki conference untuk sebagai media publikasi hasil penelitian yang dibuat berupa artikel ilmiah yang dipersentasikan. Selain sebagai media publikasi peneliti juga ingin mencari rekan untuk kolaborasi dengan peneliti lain yang memiliki bidang penelitian yang sama.

Banyaknya conference ilmiah yang dilakukan membuat banyak peneliti yang tertarik untuk meneliti tentang penyelenggaraan conference. Seperti yang dilakukan oleh $\mathrm{O}$. S. Loizides dan P. Koutsakis meneliti kualitas conference bidang Ilmu Komputer dan Teknik Komputer menggunakan metode Conference Classification Approach (CCA). Elemen yang dimiliki oleh CCA adalah paper's impact (dengan menggunakan google scholar untuk mendeteksi banyak sitasi), author recognition (dengan menggunakan h-indeks). Langkah yang dilakukan dalam CCA adalah pertama menentukan vector conference dari 4 elemen matrik yaitu PRmean(1/4), PRMean(1/3), impact, h-index, kedua mengklasifikasi dengan menggunakan $k$-means algorithm. Hasil yang diperoleh adalah mampu mengklasifikasi conference Computer Science dengan kualitas yang berbeda [1].

Penelitian oleh A. Simon-Maeda mempelajari AAAL (American Association of Applied Linguistics) conference handbook berbasis corpus. Program (CasualConc) indeks yang digunakan untuk mencari pola kata yang berulang dalam corpus AAAL dan membandingkan hasil dengan corpus yang dibuat dari buku saku conference selama delapan tahun dari 2007 sampai 2014. Proses awal sebelum dilakukan proses inti adalah dengan menghapus jadwal waktu, peta, promosi dan file data yang diindikasikan dihapus dari AAAL corpus dan meninggalkan 34,455 tipe/100,363 token dihasilkan dari program conference yang memiliki disiplin ilmu yang berbeda yaitu linguistic, sains, sosiologi, dan teknik mekanik. Hasil yang dilaporkan dalam mendemonstrasikan aturan yang menonjol dari interpersonal metadisource device dalam ringkasan AAAL conference. Dan menggunakan istilah sikap dan penghubung untuk menggambarkan interaksi natural dari alat ini. Istilah sikap adalah konsentrasi pada acara penulis mempresentasikan dirinya sendiri dan menyampaikan pendapatnya, opini dan komitmen. Penghubung lebih dari fungsi kesetaraan kata atau kalimat. [2]

Penelitian oleh S. J. Reinartz dan D. Urban tentang ranking jurnal finansial bedasarkan kualitas dan keberhasilan publikasi. Menjadikan waktu dan kesediaan uang sebagai batasan, peneliti memutuskan untuk mengikuti conference akademik dan jika demikian, conference dihubungkan dengan keluaran publikasi. Pada penelitian tersebut menampilkan ranking 47 conference finansial dan cara untuk memilih tempat conference yaitu dengan dua tahapan. Tahap pertama mencari informasi yang diperoleh dari footnotes dari 3,319 artikel penelitian yang dipublikasi dari sembilan jurnal finansial antara 2010 sampai 2013 yang hasilnya adalah patisipasi merupakan faktor penting ketika mempublikasi artikel penelitian pada jurnal finansial tingkat atas. Tahap kedua berfokus pada sampel artikel 8,946 pada 47 artikel finansial yang menampilkan bahwa status publikasi pada bulan oktober, yang berarti variasi keluaran publikasi setara dengan waktu conference [3].

Penelitian oleh N. K. Dimitrios et. all. meneliti model publikasi dalam conference akademik. Topik yang dipelajari adalah prosedur mamasukan publikasi pada conference akademik yang berdampak pada pola dan keberhasilan dan suksesnya. Hasilnya conference dari ilmu alam memiliki kualifikasi tinggi dan diakui secara akademik [4].

Penelitian oleh M. Singh et. all. mengklasifikasi tempat publikasi tingkat atas dan bukan tingkat atas. Pengklasifikasian menggunakan ConfAssist (framework untuk mengkategorisasi conference). Jumlah conference yang digunakan untuk analisis adalah 
110 dengan 22 sub kategori komputer sains. Dalam penelitian melibatkan 28 ahli untuk melakukan survei keakuratan pengklasifikasian. Hasil survei memperlihatkan bahwa 85,18\% klasifikasi dikatakan akurat [5].

Penelitian oleh M. Deveugele dan J. Silverman melakukan perankingan reabilitas conference internasional yang besar dikarenakan terdapat ketidak konsistenan diantara pimpinan reviewer karena waktu yang mendesak dalam proses review. Kesimpulan yang didapat dari penelitian tersebut memperlihatkan dengan menggunakan percobaan kalibrasi dengan menggunakan mean proses review dinyatakan tidak realibilitas dengan bukti bahwa dalam kelompok proses review hanya 3 yang memiliki nilai mean yang tinggi selebihnya terdapat 7 memiliki nilai mean yang rendah. Penanggulangan ketidak reabilitas proses review adalah dengan melakukan pelatihan terhadap reviewer yang ditunjuk [6].

Aspek yang dibahas oleh banyak penelitian yang dilakukan adalah tentang ranking dari kualitas conference. Satu hal yang tidak kalah penting dalam penyelenggaraan conference adalah tentang manajemen penerimaan artikel, proses reviewer dan pembayaran. Dalam proses-proses tersebut penggunaan sebuah portal website dibutuhkan untuk membantu dikarenakan dapat dilakukan secara online.

\section{CONFERENCE}

ICCA mendefinisikan sebuah konferensi sebagai pertemuan partisipatif dirancang untuk diskusi, fakta, pemecahan masalah dan konsultasi. Dibandingkan dengan kongres, konferensi biasanya dalam skala lebih kecil dan lebih pilih dalam karakter - fitur yang cenderung memfasilitasi pertukaran informasi. Istilah "konferensi" tidak membawa konotasi khusus untuk frekuensi. Meskipun tidak secara inheren terbatas dalam waktu, konferensi biasanya terbatas durasi dengan tujuan khusus [7].

\section{USE CASE DIAGRAM}

Use Case Diagram (UCD) menjelaskan apa yang akan dilakukan oleh sistem yang akan dibangun dan siapa yang berinteraksi dengan sistem. Use case diagram pada umumnya tersusun dari elemen actor, use case, dependency, generalization, dan association. UCD ini memberikan gambaran statis dari sistem yang sedang dibangun dan merupakan artifak dari proses analisis. Notasi yang digunakan dalam Use Case Diagram ditunjukkan pada Tabel 3.1 [8].

\section{Tabel 3. 1 Notasi Use Case Diagram}

Notasi

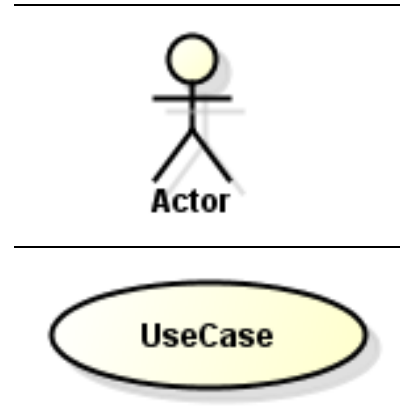

\section{Keterangan}

Actor adalah segala sesuatu yang berinteraksi dengan sistem aplikasi komputer. Jadi actor ini bisa berupa orang, perangkat keras, atau mungkin juga obyek lain dalam sistem yang sama. Biasanya yang dilakukan oleh actor adalah memberikan informasi pada sistem danlatau memerintahkan sistem untuk melakukan sesuatu.

Use case menjelaskan urutan kegiatan yang dilakukan actor dan sistem untuk mencapai suatu tujuan tertentu. Walaupun menjelaskan kegiatan namun use case hanya menjelaskan apa yang dilakukan oleh actor dan sistem, bukan bagaimana actor dan sistem melakukan kegiatan tersebut.

Association menggambarkan navigasi antar class (Navigation), berapa banyak obyek lain yang bisa berhubungan dengan satu obyek (Multiplicity antar class), dan apakah suatu class menjadi bagian dari class lainnya (Aggregation). 
Include menunjukkan bahwa suatu bagian dari elemen (yang ada di garis tanpa panah) memicu eksekusi bagian dari elemen lain (yang ada di garis panah).

Extend menunjukkan bahwa suatu bagian dari elemen di garis tanpa panah bisa disisipkan ke dalam elemen yang ada di garis dengan panah.

Generalization menunjukkan hubungan antara elemen yang

lebih umum ke elemen yang lebih spesifik.

\section{CODEIGNITER}

Web merupakan media informasi berbasis jaringan komputer yang dapat diakses di mana saja dengan biaya relatif murah. Web merupakan bentuk implementasi dari bahasa pemrograman web (web programming) [9]. Sedangkan untuk pengembangan web sendiri diperlukan bahasa (HTML) untuk dapat menampilkan tulisan,gambar, audio dan video. HTML hanya berkaitan dengan tampilan saja sedangkan bahasa pemrograman untuk melakukan koneksi ke database dan fungsi-fungsi yang lebih rumit bahasa yang digunakan salah satunya adalah PHP.

Codelgniter adalah framework web untuk bahasa pemrograman $P H P$, yang dibuat oleh Rick Ellis pada tahun 2006, penemu dan pendiri Ellislab (www.ellislab.com) [10]. Codelgniter memiliki banyak fitur (fasilitas) yang membantu para pengembang (developer) PHP untuk dapat membuat aplikasi web secara mudah dan cepat. Dibandingkan dengan framework web PHP lainnya, harus diakui bahwa Codelgniter memiliki desain yang lebih sederhana dan bersifat fleksibel (tidak kaku). Codelgniter mengizinkan para pengembang untuk menggunakan framework secara parsial atau secara keseluruhan. Ini berarti bahwa Codelgniter masih memberi kebebasan kepada para pengembang untuk menulis bagianbagian kode tertentu di dalam aplikasi menggunakan cara konvensional (tanpa framework) [10].

Codelgniter adalah framework web untuk PHP. Selain itu, Codelgniter merupakan framework web yang mengimplementasikan pola desain $M V C$. Pada teknik pemrograman menggunakan arsitektur MVC, kita akan banyak bekerja dengan pembuatan model, view, controller. Model dan controller merupakan komponen aplikasi yang berupa kelas, dan kelas merupakan jantung dari gaya pemrograman berorientasi objek [10].

\section{BLACK BOX TESTING}

Yaitu menguji perangkat lunak dari segi spesifikasi fungsional tanpa menguji desain dan kode program. Pengujian dimaksudkan untuk mengetahui apakah fungsi-fungsi, masukan, dan keluaran dari perangkat lunak sesuai dengan spesifikasi yang dibutuhkan [11].

Pengujian kotak hitam dilakukan dengan membuat kasus uji yang bersifat mencoba semua fungsi dengan memakai perangkat lunak apakah sesuai dengan spesifikasi yang dibutuhkan. Kasus uji yang dibuat untuk melakukan pengujian kotak hitam harus dibuat dengan kasus benar dan kasus salah, misalkan untuk kasus proses login maka kasus uji yang dibuat adalah [11]:

1. Jika user memasukkan nama pemakai (username) dan kata sandi (password) yang benar.

2. Jika user memasukkan nama pemakai (username) dan kata sandi (password) yang salah, misalnya nama pemakai benar tapi kata sandi salah, atau sebaliknya, atau keduanya salah. 


\section{METODOLOGI PENELITIAN}

Penelitian yang dilakukan memerlukan alat, bahan dan alur penelitian untuk dapat menganalisa hasil yang didapat

\section{1. Alat}

Alat yang digunakan untuk melakukan penelitian adalah sebagai berikut:

1. Database untuk melakukan penyimpanan data yaitu $M y S Q L$.

2. Webserver untuk melayani request dan melakukan respond dari browser yaitu apache.

3. PHP sebagai Bahasa pemrograman.

4. Framework codeigniter untuk mempermudah proses pengkodean dan pengorganisasian file dan kode.

\section{2. Bahan}

Bahan yang digunakan adalah untuk tahapan analisis alur program dari portal-portal website yang sudah ada. Portal-portal tersebut adalah sebagai berikut:

1. Easychair yang beralamat http://easychair.org

2. ICITEE yang beralamat http://icitee.ugm.ac.id/new/.

3. ICACSIS yang beralamat http://icacsis.cs.ui.ac.id/front/.

4. ICMEM yang beralamat https://icmem.sbm.itb.ac.id/.

\section{3. Alur Penelitian}

Alur penelitian yang dilakukan adalah sebagai berikut:

1. Pembuatan Analisis berupa pembuatan fungsional dan use case.

2. Pembuatan Pembuatan program.

3. Pengujian Program.

\section{HASIL DAN PEMBAHASAN}

Hal pertama dalam pembuatan sistem adalah menganalisis peran-peran tiap user dalam aplikasi yang dibuat diagram use case seperti terlihat pada gambar 7.1. Setelah mengetahui peran-peran user maka langkah selanjutnya adalah membuat list detail dari kebutuhan fungsional sistem yang dapat dilihat pada tabel 7.1 memiliki 22 kebutuhan fungsional yang meliputi 17 kebutuhan fungsional untuk administrator, lima kebutuhan fungsional untuk user dan dua kebutuhan fungsional untuk reviewer.

Tabel 7.1. Kebutuhan fungsional

\begin{tabular}{|c|c|c|}
\hline Kode & Deskripsi & Aktor \\
\hline FR01 & Manajemen data admin & Administrator \\
\hline FR02 & Manajemen data event & Administrator \\
\hline FR03 & Manajemen data penyelenggara & Administrator \\
\hline FR04 & Manajemen data topik & Administrator \\
\hline FR05 & Manajemen data keynote speaker & Administrator \\
\hline FR06 & Manajemen data venue & Administrator \\
\hline FR07 & $\begin{array}{l}\text { Manajemen data submission } \\
\text { guideline }\end{array}$ & Administrator \\
\hline FR08 & Manajemen data partner & Administrator \\
\hline FR09 & Manajemen data deadline & Administrator \\
\hline FR10 & Manajemen data setting email & Administrator \\
\hline FR11 & Manajemen data kategori & Administrator \\
\hline FR12 & Manajemen data pertanyaan & Administrator \\
\hline FR13 & Manajemen data user & $\begin{array}{c}\text { Administrator } \\
\text { User }\end{array}$ \\
\hline FR14 & Manajemen data reviewer & $\begin{array}{l}\text { Administrator, } \\
\text { Reviewer }\end{array}$ \\
\hline
\end{tabular}




\begin{tabular}{clc} 
FR15 & Penugasan reviewer & Administrator \\
\hline FR16 & Menentukan penerimaan paper & Administrator \\
\hline FR17 & Validasi pembayaran & Administrator \\
\hline FR18 & Mendaftar conference & User \\
\hline FR19 & Mengupload paper & User \\
\hline FR20 & Manajemen data paper & User \\
\hline FR21 & Upload bukti pembayaran & User \\
\hline FR22 & Mereview paper & Reviewer
\end{tabular}

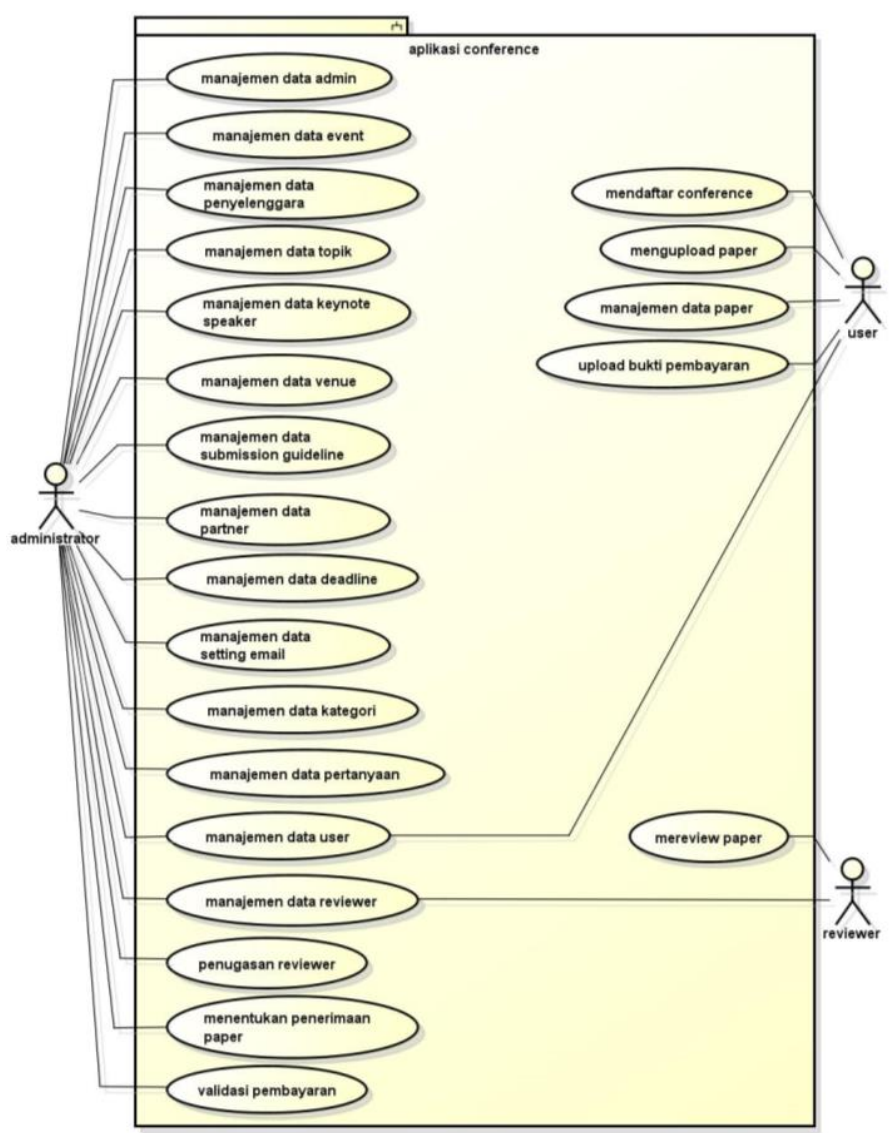

Gambar 7.1. Quality Filter Mapping

Pembuatan program adalah langkah pengkodengan dengan menggunakan bahasa pemrograman PHP dan dibantu dengan menggunakan Framework codeigniter sehingga dapat membuat sebuah website yang dapat dilihat pada gambar 7.2 merupakan halaman home dari sistem. 


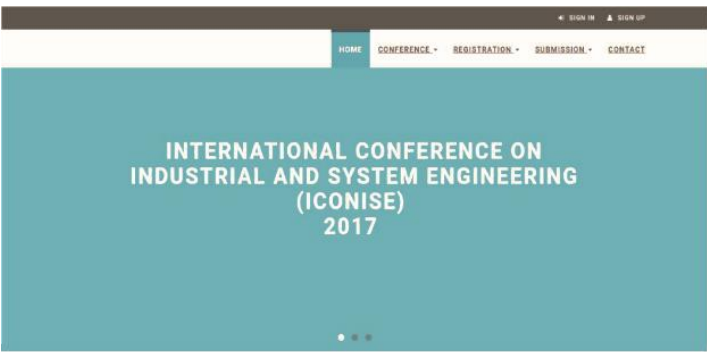

INTERNATIONAL CONFERENCE ON INDUSTRIAL AND SYSTEM ENGINEERING (ICONISE) 2017

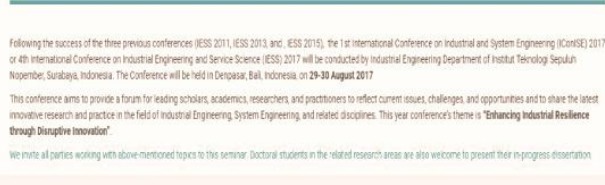

IMPORTANT DATES

Gelombang 3

Tanggal Submt
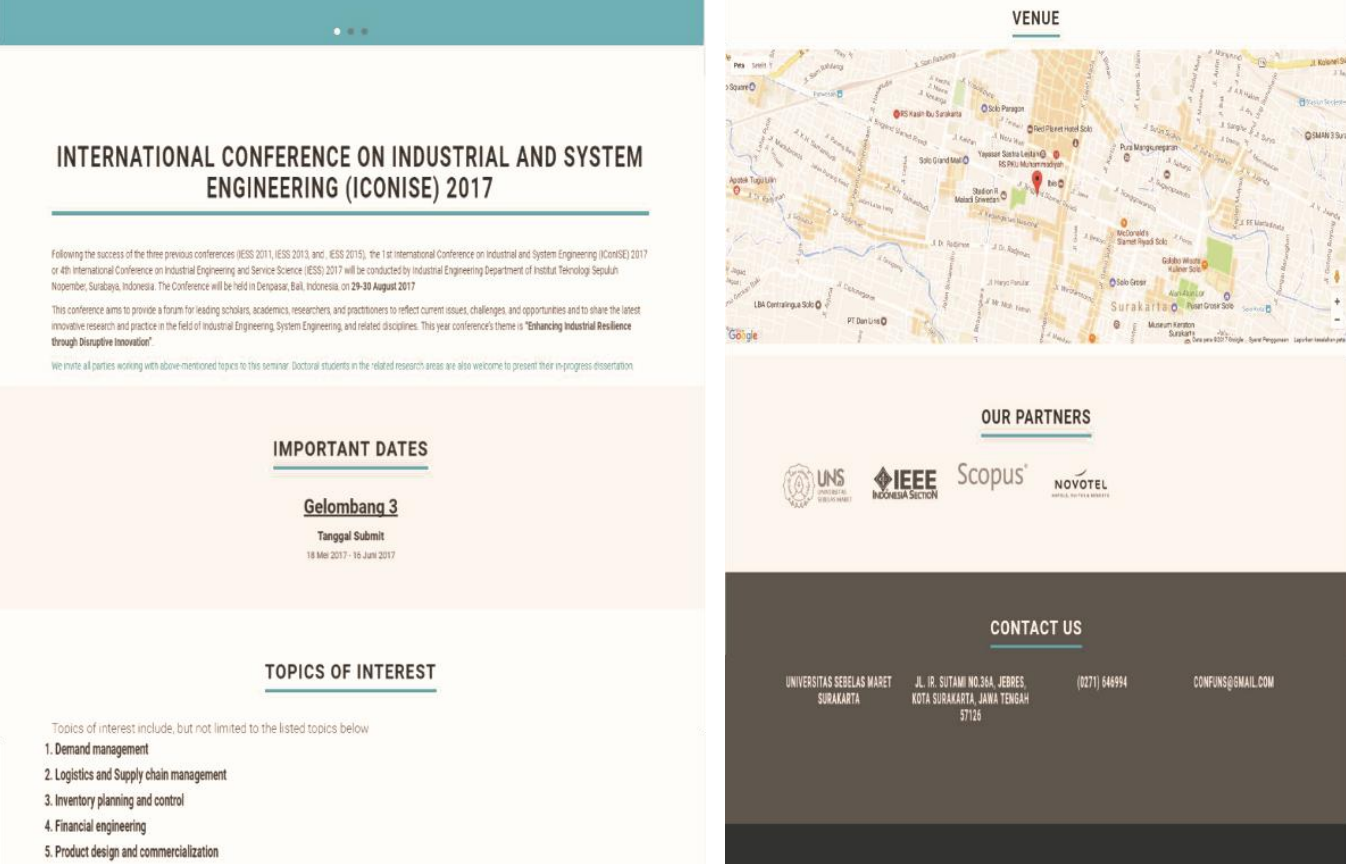

OUR PARTNERS

UNS \$IEEE SCOPUS Novoter

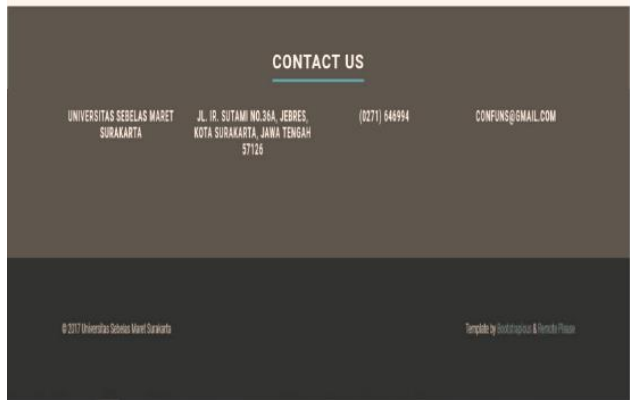

Gambar 7.2 Implementasi Halaman Home

Pengujian program dapat dilihat pada tabel 7.2. Metode pengujian yang dilakukan adalah metode pengujian blackbox. Tabel pengujian menyajikan kasus pengujian, sekenario uji, hasil yang diharapakan dan status. Status 'Berhasil' berarti hasil yang diharapkan terpenuhi sedangkan jika status 'Gagal' maka hasil yang diharapkan tidak terpenuhi.

\begin{tabular}{|c|c|c|c|c|}
\hline \multirow[b]{2}{*}{ No. } & \multicolumn{4}{|c|}{ Tabel 7.2 Tabel pengujian Black Box } \\
\hline & $\begin{array}{c}\text { Kasus } \\
\text { Pengujian }\end{array}$ & Skenario Uji & $\begin{array}{l}\text { Hasil yang } \\
\text { diharapkan }\end{array}$ & Status \\
\hline 1. & $\begin{array}{l}\text { User log in } \\
\text { pada halaman } \\
\text { website } \\
\text { conference }\end{array}$ & $\begin{array}{l}\text { User menginputkan } \\
\text { username dan } \\
\text { password }\end{array}$ & $\begin{array}{l}\text { Ketika username } \\
\text { dan password yang } \\
\text { diinputkan valid, } \\
\text { maka akan } \\
\text { menampilkan } \\
\text { halaman home user. } \\
\text { Jika username dan } \\
\text { password tidak valid } \\
\text { maka sistem akan }\end{array}$ & $\begin{array}{l}{[\sqrt{ }]} \\
\text { Berhasil } \\
{[] \text { Gagal }}\end{array}$ \\
\hline
\end{tabular}




\begin{tabular}{|c|c|c|c|c|}
\hline & & & $\begin{array}{l}\text { menampilkan pesan } \\
\text { gagal log in. }\end{array}$ & \\
\hline 2. & $\begin{array}{l}\text { Administrator } \\
\text { log in pada } \\
\text { halaman log in }\end{array}$ & $\begin{array}{l}\text { Administrator } \\
\text { menginputkan } \\
\text { username dan } \\
\text { password }\end{array}$ & $\begin{array}{l}\text { Ketika username } \\
\text { dan password yang } \\
\text { diinputkan valid, } \\
\text { maka akan } \\
\text { menampilkan } \\
\text { halaman dashboard. } \\
\text { Jika username dan } \\
\text { password tidak valid } \\
\text { maka sistem akan } \\
\text { menampilkan } \\
\text { kembali halaman log } \\
\text { in. }\end{array}$ & $\begin{array}{l}{[\sqrt{ }]} \\
\text { Berhasil } \\
{[] \text { Gagal }}\end{array}$ \\
\hline 3. & $\begin{array}{l}\text { Reviewer log in } \\
\text { pada halaman } \\
\text { log in }\end{array}$ & $\begin{array}{l}\text { Reviewer } \\
\text { menginputkan } \\
\text { username dan } \\
\text { password }\end{array}$ & $\begin{array}{l}\text { Ketika username } \\
\text { dan password yang } \\
\text { diinputkan valid, } \\
\text { maka akan } \\
\text { menampilkan } \\
\text { halaman home } \\
\text { reviewer. Jika } \\
\text { username dan } \\
\text { password tidak valid } \\
\text { maka sistem akan } \\
\text { menampilkan } \\
\text { kembali halaman log } \\
\text { in. }\end{array}$ & $\begin{array}{l}{[\sqrt{ }]} \\
\text { Berhasil } \\
{[] \text { Gagal }}\end{array}$ \\
\hline 4. & $\begin{array}{l}\text { Menampilkan } \\
\text { data } \\
\text { administrator }\end{array}$ & $\begin{array}{l}\text { Administrator } \\
\text { memilih menu profil }\end{array}$ & $\begin{array}{l}\text { Sistem menampilkan } \\
\text { data administrator }\end{array}$ & $\begin{array}{l}{[\sqrt{ }]} \\
\text { Berhasil } \\
{[] \text { Gagal }}\end{array}$ \\
\hline 5. & $\begin{array}{l}\text { Mengubah data } \\
\text { administrator }\end{array}$ & $\begin{array}{l}\text { Administrator } \\
\text { memilih action } \\
\text { update }\end{array}$ & $\begin{array}{l}\text { Sistem menyimpan } \\
\text { perubahan data } \\
\text { administrator }\end{array}$ & $\begin{array}{l}{[\sqrt{ }]} \\
\text { Berhasil } \\
\text { [] Gagal }\end{array}$ \\
\hline 6. & $\begin{array}{l}\text { Menampilkan } \\
\text { data event }\end{array}$ & $\begin{array}{l}\text { Administrator } \\
\text { memilih sub menu } \\
\text { event }\end{array}$ & $\begin{array}{l}\text { Sistem dapat } \\
\text { menampilkan daftar } \\
\text { event }\end{array}$ & $\begin{array}{l}{[\sqrt{ }]} \\
\text { Berhasil } \\
\text { [] Gagal }\end{array}$ \\
\hline 7. & $\begin{array}{l}\text { Menambah } \\
\text { data event }\end{array}$ & $\begin{array}{l}\text { Administrator } \\
\text { memilih button } \\
\text { tambah event, lalu } \\
\text { mengisi form tambah } \\
\text { event }\end{array}$ & $\begin{array}{l}\text { Sistem dapat } \\
\text { menyimpan data } \\
\text { event dan } \\
\text { menampilkan daftar } \\
\text { event }\end{array}$ & $\begin{array}{l}{[\sqrt{ }]} \\
\text { Berhasil } \\
\text { [] Gagal }\end{array}$ \\
\hline 8. & $\begin{array}{l}\text { Mengubah data } \\
\text { event }\end{array}$ & $\begin{array}{l}\text { Administrator } \\
\text { memilih button } \\
\text { update pada data } \\
\text { event yang akan } \\
\text { diubah }\end{array}$ & $\begin{array}{l}\text { Sistem dapat } \\
\text { menyimpan } \\
\text { perubahan data } \\
\text { event dan } \\
\text { menampilkan daftar } \\
\text { event }\end{array}$ & $\begin{array}{l}{[\sqrt{ }]} \\
\text { Berhasil } \\
{[] \text { Gagal }}\end{array}$ \\
\hline 9. & $\begin{array}{l}\text { Menghapus } \\
\text { data event }\end{array}$ & $\begin{array}{l}\text { Administrator } \\
\text { memilih button } \\
\text { delete pada data }\end{array}$ & $\begin{array}{l}\text { Sistem dapat } \\
\text { menghapus data } \\
\text { event yang dipilih }\end{array}$ & $\begin{array}{l}{[\sqrt{ }]} \\
\text { Berhasil } \\
{[] \text { Gagal }}\end{array}$ \\
\hline
\end{tabular}




\begin{tabular}{|c|c|c|c|c|}
\hline & & $\begin{array}{l}\text { event yang akan } \\
\text { dihapus }\end{array}$ & $\begin{array}{l}\text { dan menampilkan } \\
\text { daftar event }\end{array}$ & \\
\hline 10. & $\begin{array}{l}\text { Menampilkan } \\
\text { data } \\
\text { penyelenggara }\end{array}$ & $\begin{array}{l}\text { Administrator } \\
\text { memilih sub menu } \\
\text { penyelenggara }\end{array}$ & $\begin{array}{l}\text { Sistem dapat } \\
\text { menampilkan daftar } \\
\text { penyelenggara }\end{array}$ & $\begin{array}{l}{[\sqrt{ }]} \\
\text { Berhasil } \\
\text { [] Gagal }\end{array}$ \\
\hline 11. & $\begin{array}{l}\text { Menambah } \\
\text { data } \\
\text { penyelenggara }\end{array}$ & $\begin{array}{l}\text { Administrator } \\
\text { memilih button } \\
\text { tambah } \\
\text { penyelenggara, lalu } \\
\text { mengisi form tambah } \\
\text { penyelenggara }\end{array}$ & $\begin{array}{l}\text { Sistem dapat } \\
\text { menyimpan data } \\
\text { penyelenggara dan } \\
\text { menampilkan daftar } \\
\text { penyelenggara }\end{array}$ & $\begin{array}{l}{[\sqrt{ }]} \\
\text { Berhasil } \\
{[] \text { Gagal }}\end{array}$ \\
\hline 12. & $\begin{array}{l}\text { Mengubah data } \\
\text { penyelenggara }\end{array}$ & $\begin{array}{l}\text { Administrator } \\
\text { memilih button } \\
\text { update pada data } \\
\text { penyelenggara yang } \\
\text { akan diubah }\end{array}$ & $\begin{array}{l}\text { Sistem dapat } \\
\text { menyimpan } \\
\text { perubahan data } \\
\text { penyelenggara dan } \\
\text { menampilkan daftar } \\
\text { penyelenggara }\end{array}$ & $\begin{array}{l}{[\sqrt{ }]} \\
\text { Berhasil } \\
{[] \text { Gagal }}\end{array}$ \\
\hline 13. & $\begin{array}{l}\text { Menghapus } \\
\text { data } \\
\text { penyelenggara }\end{array}$ & $\begin{array}{l}\text { Administrator } \\
\text { memilih button } \\
\text { delete pada data } \\
\text { penyelenggara yang } \\
\text { akan dihapus }\end{array}$ & $\begin{array}{l}\text { Sistem dapat } \\
\text { menghapus data } \\
\text { penyelenggara yang } \\
\text { dipilih dan } \\
\text { menampilkan daftar } \\
\text { penyelenggara }\end{array}$ & $\begin{array}{l}{[\sqrt{ }]} \\
\text { Berhasil } \\
{[] \text { Gagal }}\end{array}$ \\
\hline 14. & $\begin{array}{l}\text { Menampilkan } \\
\text { data topik }\end{array}$ & $\begin{array}{l}\text { Administrator } \\
\text { memilih sub menu } \\
\text { topik }\end{array}$ & $\begin{array}{l}\text { Sistem dapat } \\
\text { menampilkan daftar } \\
\text { topik }\end{array}$ & $\begin{array}{l}{[\sqrt{ }]} \\
\text { Berhasil } \\
\text { [] Gagal }\end{array}$ \\
\hline 15. & $\begin{array}{l}\text { Menambah } \\
\text { data topik }\end{array}$ & $\begin{array}{l}\text { Administrator } \\
\text { memilih button } \\
\text { tambah topik, lalu } \\
\text { mengisi form tambah } \\
\text { topik }\end{array}$ & $\begin{array}{l}\text { Sistem dapat } \\
\text { menyimpan data } \\
\text { topik dan } \\
\text { menampilkan daftar } \\
\text { topik }\end{array}$ & $\begin{array}{l}{[\sqrt{ }]} \\
\text { Berhasil } \\
{[] \text { Gagal }}\end{array}$ \\
\hline 16. & $\begin{array}{l}\text { Mengubah data } \\
\text { topik }\end{array}$ & $\begin{array}{l}\text { Administrator } \\
\text { memilih button } \\
\text { update pada data } \\
\text { topik yang akan } \\
\text { diubah }\end{array}$ & $\begin{array}{l}\text { Sistem dapat } \\
\text { menyimpan } \\
\text { perubahan data } \\
\text { topik dan } \\
\text { menampilkan daftar } \\
\text { topik }\end{array}$ & $\begin{array}{l}{[\sqrt{ }]} \\
\text { Berhasil } \\
{[] \text { Gagal }}\end{array}$ \\
\hline 17. & $\begin{array}{l}\text { Menghapus } \\
\text { data topik }\end{array}$ & $\begin{array}{l}\text { Administrator } \\
\text { memilih button } \\
\text { delete pada data } \\
\text { topik yang akan } \\
\text { dihapus }\end{array}$ & $\begin{array}{l}\text { Sistem dapat } \\
\text { menghapus data } \\
\text { topik yang dipilih dan } \\
\text { menampilkan daftar } \\
\text { topik }\end{array}$ & $\begin{array}{l}{[\sqrt{ }]} \\
\text { Berhasil } \\
{[] \text { Gagal }}\end{array}$ \\
\hline 18. & $\begin{array}{l}\text { Menampilkan } \\
\text { data keynote } \\
\text { speaker }\end{array}$ & $\begin{array}{l}\text { Administrator } \\
\text { memilih sub menu } \\
\text { keynote speaker }\end{array}$ & $\begin{array}{l}\text { Sistem dapat } \\
\text { menampilkan daftar } \\
\text { keynote speaker }\end{array}$ & $\begin{array}{l}{[\sqrt{ }]} \\
\text { Berhasil } \\
{[] \text { Gagal }}\end{array}$ \\
\hline 19. & $\begin{array}{l}\text { Menambah } \\
\text { data keynote } \\
\text { speaker }\end{array}$ & $\begin{array}{l}\text { Administrator } \\
\text { memilih button } \\
\text { tambah keynote } \\
\text { speaker, lalu mengisi } \\
\text { form tambah keynote } \\
\text { speaker }\end{array}$ & $\begin{array}{l}\text { Sistem dapat } \\
\text { menyimpan data } \\
\text { keynote speaker dan } \\
\text { menampilkan daftar } \\
\text { keynote speaker }\end{array}$ & $\begin{array}{l}{[\sqrt{ }]} \\
\text { Berhasil } \\
{[] \text { Gagal }}\end{array}$ \\
\hline
\end{tabular}




\begin{tabular}{|c|c|c|c|c|}
\hline 20. & $\begin{array}{l}\text { Mengubah data } \\
\text { keynote } \\
\text { speaker }\end{array}$ & $\begin{array}{l}\text { Administrator } \\
\text { memilih button } \\
\text { update pada data } \\
\text { keynote speaker } \\
\text { yang akan diubah }\end{array}$ & $\begin{array}{l}\text { Sistem dapat } \\
\text { menyimpan } \\
\text { perubahan data } \\
\text { keynote speaker } \\
\text { dan menampilkan } \\
\text { keynote speaker }\end{array}$ & $\begin{array}{l}{[\sqrt{ }]} \\
\text { Berhasil } \\
{[] \text { Gagal }}\end{array}$ \\
\hline 21. & $\begin{array}{l}\text { Menghapus } \\
\text { data keynote } \\
\text { speaker }\end{array}$ & $\begin{array}{l}\text { Administrator } \\
\text { memilih button } \\
\text { delete pada data } \\
\text { keynote speaker } \\
\text { yang akan dihapus }\end{array}$ & $\begin{array}{l}\text { Sistem dapat } \\
\text { menghapus data } \\
\text { keynote speaker } \\
\text { yang dipilih dan } \\
\text { menampilkan daftar } \\
\text { keynote speaker }\end{array}$ & $\begin{array}{l}{[\sqrt{ }]} \\
\text { Berhasil } \\
{[] \text { Gagal }}\end{array}$ \\
\hline 22. & $\begin{array}{l}\text { Menampilkan } \\
\text { data venue }\end{array}$ & $\begin{array}{l}\text { Administrator } \\
\text { memilih sub menu } \\
\text { venue }\end{array}$ & $\begin{array}{l}\text { Sistem dapat } \\
\text { menampilkan daftar } \\
\text { venue }\end{array}$ & $\begin{array}{l}{[\sqrt{ }]} \\
\text { Berhasil } \\
{[] \text { Gagal }}\end{array}$ \\
\hline 23. & $\begin{array}{l}\text { Menambah } \\
\text { data venue }\end{array}$ & $\begin{array}{l}\text { Administrator } \\
\text { memilih button } \\
\text { tambah venue, lalu } \\
\text { mengisi form tambah } \\
\text { venue }\end{array}$ & $\begin{array}{l}\text { Sistem dapat } \\
\text { menyimpan data } \\
\text { venue dan } \\
\text { menampilkan daftar } \\
\text { venue }\end{array}$ & $\begin{array}{l}{[\sqrt{ }]} \\
\text { Berhasil } \\
{[] \text { Gagal }}\end{array}$ \\
\hline 24. & $\begin{array}{l}\text { Mengubah data } \\
\text { venue }\end{array}$ & $\begin{array}{l}\text { Administrator } \\
\text { memilih button } \\
\text { update pada data } \\
\text { venue yang akan } \\
\text { diubah }\end{array}$ & $\begin{array}{l}\text { Sistem dapat } \\
\text { menyimpan } \\
\text { perubahan data } \\
\text { venue dan } \\
\text { menampilkan daftar } \\
\text { venue }\end{array}$ & $\begin{array}{l}{[\sqrt{ }]} \\
\text { Berhasil } \\
{[] \text { Gagal }}\end{array}$ \\
\hline 25. & $\begin{array}{l}\text { Menghapus } \\
\text { data venue }\end{array}$ & $\begin{array}{l}\text { Administrator } \\
\text { memilih button } \\
\text { delete pada data } \\
\text { venue yang akan } \\
\text { dihapus }\end{array}$ & $\begin{array}{l}\text { Sistem dapat } \\
\text { menghapus data } \\
\text { venue yang dipilih } \\
\text { dan menampilkan } \\
\text { daftar venue }\end{array}$ & $\begin{array}{l}{[\sqrt{ }]} \\
\text { Berhasil } \\
{[] \text { Gagal }}\end{array}$ \\
\hline 26. & $\begin{array}{l}\text { Menampilkan } \\
\text { data } \\
\text { submission } \\
\text { guideline }\end{array}$ & $\begin{array}{l}\text { Administrator } \\
\text { memilih sub menu } \\
\text { submission guideline }\end{array}$ & $\begin{array}{l}\text { Sistem dapat } \\
\text { menampilkan daftar } \\
\text { submission guideline }\end{array}$ & $\begin{array}{l}{[\sqrt{ }]} \\
\text { Berhasil } \\
{[] \text { Gagal }}\end{array}$ \\
\hline 27. & $\begin{array}{l}\text { Menambah } \\
\text { data } \\
\text { submission } \\
\text { guideline }\end{array}$ & $\begin{array}{l}\text { Administrator } \\
\text { memilih button } \\
\text { tambah submission } \\
\text { guideline, lalu } \\
\text { mengisi form tambah } \\
\text { submission guideline }\end{array}$ & $\begin{array}{l}\text { Sistem dapat } \\
\text { menyimpan data } \\
\text { submission guideline } \\
\text { dan menampilkan } \\
\text { daftar submission } \\
\text { guideline }\end{array}$ & $\begin{array}{l}{[\sqrt{ }]} \\
\text { Berhasil } \\
{[] \text { Gagal }}\end{array}$ \\
\hline 28. & $\begin{array}{l}\text { Mengubah data } \\
\text { submission } \\
\text { guideline }\end{array}$ & $\begin{array}{l}\text { Administrator } \\
\text { memilih button } \\
\text { update pada data } \\
\text { submission guideline } \\
\text { yang akan diubah }\end{array}$ & $\begin{array}{l}\text { Sistem dapat } \\
\text { menyimpan } \\
\text { perubahan data } \\
\text { submission guideline } \\
\text { dan menampilkan } \\
\text { daftar submission } \\
\text { guideline }\end{array}$ & $\begin{array}{l}{[\sqrt{ }]} \\
\text { Berhasil } \\
{[] \text { Gagal }}\end{array}$ \\
\hline 29. & $\begin{array}{l}\text { Menghapus } \\
\text { data }\end{array}$ & $\begin{array}{l}\text { Administrator } \\
\text { memilih button } \\
\text { delete pada data }\end{array}$ & $\begin{array}{l}\text { Sistem dapat } \\
\text { menghapus data } \\
\text { submission guideline }\end{array}$ & $\begin{array}{l}{[\sqrt{ }]} \\
\text { Berhasil } \\
{[] \text { Gagal }}\end{array}$ \\
\hline
\end{tabular}




\begin{tabular}{|c|c|c|c|c|}
\hline & $\begin{array}{l}\text { submission } \\
\text { guideline }\end{array}$ & $\begin{array}{l}\text { submission guideline } \\
\text { yang akan dihapus }\end{array}$ & $\begin{array}{l}\text { yang dipilih dan } \\
\text { menampilkan daftar } \\
\text { submission guideline }\end{array}$ & \\
\hline 30. & $\begin{array}{l}\text { Menampilkan } \\
\text { data partner }\end{array}$ & $\begin{array}{l}\text { Administrator } \\
\text { memilih sub menu } \\
\text { partner }\end{array}$ & $\begin{array}{l}\text { Sistem dapat } \\
\text { menampilkan daftar } \\
\text { partner }\end{array}$ & $\begin{array}{l}{[\sqrt{ }]} \\
\text { Berhasil } \\
\text { [] Gagal }\end{array}$ \\
\hline 31. & $\begin{array}{l}\text { Menambah } \\
\text { data partner }\end{array}$ & $\begin{array}{l}\text { Administrator } \\
\text { memilih button } \\
\text { tambah partner, lalu } \\
\text { mengisi form tambah } \\
\text { partner }\end{array}$ & $\begin{array}{l}\text { Sistem dapat } \\
\text { menyimpan data } \\
\text { partner dan } \\
\text { menampilkan daftar } \\
\text { partner }\end{array}$ & $\begin{array}{l}{[\sqrt{ }]} \\
\text { Berhasil } \\
{[] \text { Gagal }}\end{array}$ \\
\hline 32. & $\begin{array}{l}\text { Mengubah data } \\
\text { partner }\end{array}$ & $\begin{array}{l}\text { Administrator } \\
\text { memilih button } \\
\text { update pada data } \\
\text { partner yang akan } \\
\text { diubah }\end{array}$ & $\begin{array}{l}\text { Sistem dapat } \\
\text { menyimpan } \\
\text { perubahan data } \\
\text { partner dan } \\
\text { menampilkan daftar } \\
\text { partner }\end{array}$ & $\begin{array}{l}{[\sqrt{ }]} \\
\text { Berhasil } \\
{[] \text { Gagal }}\end{array}$ \\
\hline 33. & $\begin{array}{l}\text { Menghapus } \\
\text { data partner }\end{array}$ & $\begin{array}{l}\text { Administrator } \\
\text { memilih button } \\
\text { delete pada data } \\
\text { partner yang akan } \\
\text { dihapus }\end{array}$ & $\begin{array}{l}\text { Sistem dapat } \\
\text { menghapus data } \\
\text { partner yang dipilih } \\
\text { dan menampilkan } \\
\text { daftar partner }\end{array}$ & $\begin{array}{l}{[\sqrt{ }]} \\
\text { Berhasil } \\
{[] \text { Gagal }}\end{array}$ \\
\hline 34. & $\begin{array}{l}\text { Menampilkan } \\
\text { data deadline }\end{array}$ & $\begin{array}{l}\text { Administrator } \\
\text { memilih sub menu } \\
\text { deadline }\end{array}$ & $\begin{array}{l}\text { Sistem dapat } \\
\text { menampilkan daftar } \\
\text { deadline }\end{array}$ & $\begin{array}{l}\sqrt{ }] \\
\text { Berhasil } \\
\text { [] Gagal }\end{array}$ \\
\hline 35. & $\begin{array}{l}\text { Menambah } \\
\text { data deadline }\end{array}$ & $\begin{array}{l}\text { Administrator } \\
\text { memilih button } \\
\text { tambah deadline, } \\
\text { lalu mengisi form } \\
\text { tambah deadline }\end{array}$ & $\begin{array}{l}\text { Sistem dapat } \\
\text { menyimpan data } \\
\text { deadline dan } \\
\text { menampilkan daftar } \\
\text { deadline }\end{array}$ & $\begin{array}{l}{[\sqrt{ }]} \\
\text { Berhasil } \\
{[] \text { Gagal }}\end{array}$ \\
\hline 36. & $\begin{array}{l}\text { Mengubah data } \\
\text { deadline }\end{array}$ & $\begin{array}{l}\text { Administrator } \\
\text { memilih button } \\
\text { update pada data } \\
\text { deadline yang akan } \\
\text { diubah }\end{array}$ & $\begin{array}{l}\text { Sistem dapat } \\
\text { menyimpan } \\
\text { perubahan data } \\
\text { deadline dan } \\
\text { menampilkan daftar } \\
\text { deadline }\end{array}$ & $\begin{array}{l}{[\sqrt{ }]} \\
\text { Berhasil } \\
{[] \text { Gagal }}\end{array}$ \\
\hline 37. & $\begin{array}{l}\text { Menghapus } \\
\text { data deadline }\end{array}$ & $\begin{array}{l}\text { Administrator } \\
\text { memilih button } \\
\text { delete pada data } \\
\text { deadline yang akan } \\
\text { dihapus }\end{array}$ & $\begin{array}{l}\text { Sistem dapat } \\
\text { menghapus data } \\
\text { deadline yang dipilih } \\
\text { dan menampilkan } \\
\text { daftar deadline }\end{array}$ & $\begin{array}{l}{[\sqrt{ }]} \\
\text { Berhasil } \\
{[] \text { Gagal }}\end{array}$ \\
\hline 38. & $\begin{array}{l}\text { Menambah } \\
\text { data jenis } \\
\text { deadline }\end{array}$ & $\begin{array}{l}\text { Administrator } \\
\text { memilih button } \\
\text { lengkapi jenis } \\
\text { deadline dan } \\
\text { mengisi form jenis } \\
\text { deadline }\end{array}$ & $\begin{array}{l}\text { Sistem dapat } \\
\text { menyimpan data } \\
\text { jenis deadline }\end{array}$ & $\begin{array}{l}{[\sqrt{ }]} \\
\text { Berhasil } \\
{[] \text { Gagal }}\end{array}$ \\
\hline 39. & $\begin{array}{l}\text { Mengubah data } \\
\text { deadline }\end{array}$ & $\begin{array}{l}\text { Administrator } \\
\text { memilih button } \\
\text { update pada data }\end{array}$ & $\begin{array}{l}\text { Sistem dapat } \\
\text { menyimpan } \\
\text { perubahan data jenis } \\
\text { deadline }\end{array}$ & $\begin{array}{l}{[\sqrt{ }]} \\
\text { Berhasil } \\
{[] \text { Gagal }}\end{array}$ \\
\hline
\end{tabular}


jenis deadline yang akan diubah

\begin{tabular}{|c|c|c|c|c|}
\hline 40. & $\begin{array}{l}\text { Menghapus } \\
\text { data jenis } \\
\text { deadline }\end{array}$ & $\begin{array}{l}\text { Administrator } \\
\text { memilih button } \\
\text { delete pada data } \\
\text { jenis deadline yang } \\
\text { akan dihapus }\end{array}$ & $\begin{array}{l}\text { Sistem dapat } \\
\text { menghapus data } \\
\text { jenis deadline yang } \\
\text { dipilih }\end{array}$ & $\begin{array}{l}{[\sqrt{ }]} \\
\text { Berhasil } \\
{[] \text { Gagal }}\end{array}$ \\
\hline 41. & $\begin{array}{l}\text { Menampilkan } \\
\text { data camera } \\
\text { ready }\end{array}$ & $\begin{array}{l}\text { Administrator } \\
\text { memilih sub menu } \\
\text { camera ready }\end{array}$ & $\begin{array}{l}\text { Sistem dapat } \\
\text { menampilkan daftar } \\
\text { camera ready }\end{array}$ & $\begin{array}{l}{[\sqrt{ }]} \\
\text { Berhasil } \\
\text { [] Gagal }\end{array}$ \\
\hline 42. & $\begin{array}{l}\text { Menambah } \\
\text { data camera } \\
\text { ready }\end{array}$ & $\begin{array}{l}\text { Administrator } \\
\text { memilih button } \\
\text { tambah camera } \\
\text { ready, lalu mengisi } \\
\text { form tambah camera } \\
\text { ready }\end{array}$ & $\begin{array}{l}\text { Sistem dapat } \\
\text { menyimpan data } \\
\text { camera ready dan } \\
\text { menampilkan daftar } \\
\text { camera ready }\end{array}$ & $\begin{array}{l}{[\sqrt{ }]} \\
\text { Berhasil } \\
\text { [] Gagal }\end{array}$ \\
\hline 43. & $\begin{array}{l}\text { Mengubah data } \\
\text { camera ready }\end{array}$ & $\begin{array}{l}\text { Administrator } \\
\text { memilih button } \\
\text { update pada data } \\
\text { camera ready yang } \\
\text { akan diubah }\end{array}$ & $\begin{array}{l}\text { Sistem dapat } \\
\text { menyimpan } \\
\text { perubahan data } \\
\text { camera ready dan } \\
\text { menampilkan daftar } \\
\text { camera ready }\end{array}$ & $\begin{array}{l}{[\sqrt{ }]} \\
\text { Berhasil } \\
{[] \text { Gagal }}\end{array}$ \\
\hline 44. & $\begin{array}{l}\text { Menghapus } \\
\text { data camera } \\
\text { ready }\end{array}$ & $\begin{array}{l}\text { Administrator } \\
\text { memilih button } \\
\text { delete pada data } \\
\text { camera ready yang } \\
\text { akan dihapus }\end{array}$ & $\begin{array}{l}\text { Sistem dapat } \\
\text { menghapus data } \\
\text { camera ready yang } \\
\text { dipilih dan } \\
\text { menampilkan daftar } \\
\text { camera ready }\end{array}$ & $\begin{array}{l}{[\sqrt{ }]} \\
\text { Berhasil } \\
{[] \text { Gagal }}\end{array}$ \\
\hline 45. & $\begin{array}{l}\text { Menampilkan } \\
\text { data setting } \\
\text { email }\end{array}$ & $\begin{array}{l}\text { Administrator } \\
\text { memilih sub menu } \\
\text { setting email }\end{array}$ & $\begin{array}{l}\text { Sistem dapat } \\
\text { menampilkan daftar } \\
\text { setting email }\end{array}$ & $\begin{array}{l}{[\sqrt{ }]} \\
\text { Berhasil } \\
\text { [] Gagal }\end{array}$ \\
\hline 46. & $\begin{array}{l}\text { Menambah } \\
\text { data setting } \\
\text { email }\end{array}$ & $\begin{array}{l}\text { Administrator } \\
\text { memilih button } \\
\text { tambah setting } \\
\text { email, lalu mengisi } \\
\text { form tambah setting } \\
\text { email }\end{array}$ & $\begin{array}{l}\text { Sistem dapat } \\
\text { menyimpan data } \\
\text { setting email dan } \\
\text { menampilkan daftar } \\
\text { setting email }\end{array}$ & $\begin{array}{l}{[\sqrt{ }]} \\
\text { Berhasil } \\
\text { [] Gagal }\end{array}$ \\
\hline 47. & $\begin{array}{l}\text { Mengubah data } \\
\text { setting email }\end{array}$ & $\begin{array}{l}\text { Administrator } \\
\text { memilih button } \\
\text { update pada data } \\
\text { setting email yang } \\
\text { akan diubah }\end{array}$ & $\begin{array}{l}\text { Sistem dapat } \\
\text { menyimpan } \\
\text { perubahan data } \\
\text { setting email dan } \\
\text { menampilkan daftar } \\
\text { setting email }\end{array}$ & $\begin{array}{l}{[\sqrt{ }]} \\
\text { Berhasil } \\
{[] \text { Gagal }}\end{array}$ \\
\hline 48. & $\begin{array}{l}\text { Menghapus } \\
\text { data setting } \\
\text { email }\end{array}$ & $\begin{array}{l}\text { Administrator } \\
\text { memilih button } \\
\text { delete pada data } \\
\text { setting email yang } \\
\text { akan dihapus }\end{array}$ & $\begin{array}{l}\text { Sistem dapat } \\
\text { menghapus data } \\
\text { setting email yang } \\
\text { dipilih dan } \\
\text { menampilkan daftar } \\
\text { setting email }\end{array}$ & $\begin{array}{l}{[\sqrt{ }]} \\
\text { Berhasil } \\
\text { [] Gagal }\end{array}$ \\
\hline
\end{tabular}




\begin{tabular}{|c|c|c|c|c|}
\hline 49. & $\begin{array}{l}\text { Menampilkan } \\
\text { data kategori }\end{array}$ & $\begin{array}{l}\text { Administrator } \\
\text { memilih sub menu } \\
\text { kategori }\end{array}$ & $\begin{array}{l}\text { Sistem dapat } \\
\text { menampilkan daftar } \\
\text { kategori }\end{array}$ & $\begin{array}{l}{[\sqrt{ }]} \\
\text { Berhasil } \\
{[] \text { Gagal }}\end{array}$ \\
\hline 50. & $\begin{array}{l}\text { Menambah } \\
\text { data kategori }\end{array}$ & $\begin{array}{l}\text { Administrator } \\
\text { memilih button } \\
\text { tambah kategori, lalu } \\
\text { mengisi form tambah } \\
\text { kategori }\end{array}$ & $\begin{array}{l}\text { Sistem dapat } \\
\text { menyimpan data } \\
\text { kategori dan } \\
\text { menampilkan daftar } \\
\text { kategori }\end{array}$ & $\begin{array}{l}{[\sqrt{ }]} \\
\text { Berhasil } \\
\text { [] Gagal }\end{array}$ \\
\hline 51. & $\begin{array}{l}\text { Mengubah data } \\
\text { kategori }\end{array}$ & $\begin{array}{l}\text { Administrator } \\
\text { memilih button } \\
\text { update pada data } \\
\text { kategori yang akan } \\
\text { diubah }\end{array}$ & $\begin{array}{l}\text { Sistem dapat } \\
\text { menyimpan } \\
\text { perubahan data } \\
\text { kategori dan } \\
\text { menampilkan daftar } \\
\text { kategori }\end{array}$ & $\begin{array}{l}{[\sqrt{ }]} \\
\text { Berhasil } \\
{[] \text { Gagal }}\end{array}$ \\
\hline 52. & $\begin{array}{l}\text { Menghapus } \\
\text { data kategori }\end{array}$ & $\begin{array}{l}\text { Administrator } \\
\text { memilih button } \\
\text { delete pada data } \\
\text { kategori yang akan } \\
\text { dihapus }\end{array}$ & $\begin{array}{l}\text { Sistem dapat } \\
\text { menghapus data } \\
\text { kategori yang dipilih } \\
\text { dan menampilkan } \\
\text { daftar kategori }\end{array}$ & $\begin{array}{l}{[\sqrt{ }]} \\
\text { Berhasil } \\
{[] \text { Gagal }}\end{array}$ \\
\hline 53. & $\begin{array}{l}\text { Menampilkan } \\
\text { data } \\
\text { pertanyaan }\end{array}$ & $\begin{array}{l}\text { Administrator } \\
\text { memilih sub menu } \\
\text { pertanyaan }\end{array}$ & $\begin{array}{l}\text { Sistem dapat } \\
\text { menampilkan daftar } \\
\text { pertanyaan }\end{array}$ & $\begin{array}{l}{[\sqrt{ }]} \\
\text { Berhasil } \\
\text { [] Gagal }\end{array}$ \\
\hline 54. & $\begin{array}{l}\text { Menambah } \\
\text { data } \\
\text { pertanyaan }\end{array}$ & $\begin{array}{l}\text { Administrator } \\
\text { memilih button } \\
\text { tambah pertanyaan, } \\
\text { lalu mengisi form } \\
\text { tambah pertanyaan }\end{array}$ & $\begin{array}{l}\text { Sistem dapat } \\
\text { menyimpan data } \\
\text { pertanyaan dan } \\
\text { menampilkan daftar } \\
\text { pertanyaan }\end{array}$ & $\begin{array}{l}{[\sqrt{ }]} \\
\text { Berhasil } \\
\text { [] Gagal }\end{array}$ \\
\hline 55. & $\begin{array}{l}\text { Mengubah data } \\
\text { pertanyaan }\end{array}$ & $\begin{array}{l}\text { Administrator } \\
\text { memilih button } \\
\text { update pada data } \\
\text { pertanyaan yang } \\
\text { akan diubah }\end{array}$ & $\begin{array}{l}\text { Sistem dapat } \\
\text { menyimpan } \\
\text { perubahan data } \\
\text { pertanyaan dan } \\
\text { menampilkan daftar } \\
\text { pertanyaan }\end{array}$ & $\begin{array}{l}{[\sqrt{ }]} \\
\text { Berhasil } \\
{[] \text { Gagal }}\end{array}$ \\
\hline 56. & $\begin{array}{l}\text { Menghapus } \\
\text { data } \\
\text { pertanyaan }\end{array}$ & $\begin{array}{l}\text { Administrator } \\
\text { memilih button } \\
\text { delete pada data } \\
\text { pertanyaan yang } \\
\text { akan dihapus }\end{array}$ & $\begin{array}{l}\text { Sistem dapat } \\
\text { menghapus data } \\
\text { pertanyaan yang } \\
\text { dipilih dan } \\
\text { menampilkan daftar } \\
\text { pertanyaan }\end{array}$ & $\begin{array}{l}{[\sqrt{ }]} \\
\text { Berhasil } \\
{[] \text { Gagal }}\end{array}$ \\
\hline 57. & $\begin{array}{l}\text { Menampilkan } \\
\text { data reviewer }\end{array}$ & $\begin{array}{l}\text { Administrator } \\
\text { memilih menu data } \\
\text { reviewer }\end{array}$ & $\begin{array}{l}\text { Sistem dapat } \\
\text { menampilkan daftar } \\
\text { reviewer }\end{array}$ & $\begin{array}{l}{[\sqrt{ }]} \\
\text { Berhasil } \\
{[] \text { Gagal }}\end{array}$ \\
\hline 58. & $\begin{array}{l}\text { Menambah } \\
\text { data reviewer }\end{array}$ & $\begin{array}{l}\text { Administrator } \\
\text { memilih button } \\
\text { tambah reviewer, } \\
\text { lalu mengisi form } \\
\text { tambah reviewer }\end{array}$ & $\begin{array}{l}\text { Sistem dapat } \\
\text { menyimpan data } \\
\text { reviewer dan } \\
\text { menampilkan daftar } \\
\text { reviewer }\end{array}$ & $\begin{array}{l}{[\sqrt{ }]} \\
\text { Berhasil } \\
{[] \text { Gagal }}\end{array}$ \\
\hline 59. & $\begin{array}{l}\text { Menampilkan } \\
\text { data user }\end{array}$ & $\begin{array}{l}\text { Administrator } \\
\text { memilih menu data } \\
\text { user }\end{array}$ & $\begin{array}{l}\text { Sistem dapat } \\
\text { menampilkan daftar } \\
\text { user yang mendaftar } \\
\text { conference }\end{array}$ & $\begin{array}{l}{[\sqrt{ }]} \\
\text { Berhasil } \\
{[] \text { Gagal }}\end{array}$ \\
\hline
\end{tabular}




\begin{tabular}{|c|c|c|c|c|}
\hline 60. & $\begin{array}{l}\text { Menentukan } \\
\text { penugasan } \\
\text { reviewer }\end{array}$ & $\begin{array}{l}\text { Administrator } \\
\text { memilih menu } \\
\text { penugasan reviewer, } \\
\text { kemudian } \\
\text { menentukan } \\
\text { reviewer untuk tiap- } \\
\text { tiap paper. Setelah } \\
\text { itu, administrator } \\
\text { memilih action send } \\
\text { request untuk } \\
\text { mengirimkan } \\
\text { notifikasi ke reviewer } \\
\text { melalui email }\end{array}$ & $\begin{array}{l}\text { Sistem dapat } \\
\text { menyimpan daftar } \\
\text { reviewer yang } \\
\text { ditugaskan untuk } \\
\text { mereview paper dan } \\
\text { reviewer menerima } \\
\text { notifikasi email }\end{array}$ & $\begin{array}{l}{[\sqrt{ }]} \\
\text { Berhasil } \\
\text { [] Gagal }\end{array}$ \\
\hline 61. & $\begin{array}{l}\text { Menentukan } \\
\text { penerimaan } \\
\text { paper }\end{array}$ & $\begin{array}{l}\text { Administrator } \\
\text { memilih menu } \\
\text { penerimaan paper, } \\
\text { kemudian } \\
\text { menentukan status } \\
\text { penerimaan paper } \\
\text { dan memilih button } \\
\text { save }\end{array}$ & $\begin{array}{l}\text { Sistem dapat } \\
\text { menyimpan status } \\
\text { penerimaan paper } \\
\text { dan user menerima } \\
\text { notifikasi email yang } \\
\text { berisi hasil review }\end{array}$ & $\begin{array}{l}{[\sqrt{ }]} \\
\text { Berhasil } \\
{[] \text { Gagal }}\end{array}$ \\
\hline 62. & $\begin{array}{l}\text { Validasi } \\
\text { pembayaran }\end{array}$ & $\begin{array}{l}\text { Administrator } \\
\text { memilih menu } \\
\text { pembayaran dan } \\
\text { memilih data } \\
\text { pembayaran yang } \\
\text { ingin divalidasi }\end{array}$ & $\begin{array}{l}\text { Sistem dapat } \\
\text { mengubah status } \\
\text { pembayaran user }\end{array}$ & $\begin{array}{l}{[\sqrt{ }]} \\
\text { Berhasil } \\
{[] \text { Gagal }}\end{array}$ \\
\hline 63. & $\begin{array}{l}\text { Menampilkan } \\
\text { daftar paper } \\
\text { yang di review }\end{array}$ & $\begin{array}{l}\text { Reviewer memilih } \\
\text { menu list paper }\end{array}$ & $\begin{array}{l}\text { Sistem menampilkan } \\
\text { daftar paper yang } \\
\text { harus di review }\end{array}$ & $\begin{array}{l}{[\sqrt{ }]} \\
\text { Berhasil } \\
\text { [] Gagal }\end{array}$ \\
\hline 64. & $\begin{array}{l}\text { Memberikan } \\
\text { review }\end{array}$ & $\begin{array}{l}\text { Reviewer mengisi } \\
\text { form review dan } \\
\text { memilih button save }\end{array}$ & $\begin{array}{l}\text { Sistem menyimpan } \\
\text { hasil review dan } \\
\text { menampilkan status } \\
\text { rekomendasi dari } \\
\text { paper yang telah di } \\
\text { review }\end{array}$ & $\begin{array}{l}{[\sqrt{ }]} \\
\text { Berhasil } \\
\text { [] Gagal }\end{array}$ \\
\hline 65. & $\begin{array}{l}\text { Mengubah } \\
\text { profil reviewer }\end{array}$ & $\begin{array}{l}\text { Reviewer memilih } \\
\text { menu profil, } \\
\text { kemudian mengubah } \\
\text { data diri reviewer }\end{array}$ & $\begin{array}{l}\text { Sistem dapat } \\
\text { menyimpan } \\
\text { perubahan data diri } \\
\text { reviewer }\end{array}$ & $\begin{array}{l}{[\sqrt{ }]} \\
\text { Berhasil } \\
\text { [] Gagal }\end{array}$ \\
\hline 66. & $\begin{array}{l}\text { Mendaftar } \\
\text { conference }\end{array}$ & $\begin{array}{l}\text { User mengisi form } \\
\text { pendaftaran } \\
\text { conference dan } \\
\text { memilih button save }\end{array}$ & $\begin{array}{l}\text { Sistem menyimpan } \\
\text { data user dan user } \\
\text { menerima notifikasi } \\
\text { melalui email }\end{array}$ & $\begin{array}{l}{[\sqrt{ }]} \\
\text { Berhasil } \\
\text { [] Gagal }\end{array}$ \\
\hline 67. & Upload paper & $\begin{array}{l}\text { User memilih menu } \\
\text { upload paper, } \\
\text { mengisi form upload, } \\
\text { dan memilih button } \\
\text { save }\end{array}$ & $\begin{array}{l}\text { Sistem dapat } \\
\text { menyimpan data } \\
\text { paper }\end{array}$ & $\begin{array}{l}\sqrt{ }] \\
\text { Berhasil } \\
{[] \text { Gagal }}\end{array}$ \\
\hline
\end{tabular}




\begin{tabular}{|c|c|c|c|c|}
\hline 68. & $\begin{array}{l}\text { Menampilkan } \\
\text { daftar paper }\end{array}$ & $\begin{array}{l}\text { User memilih menu } \\
\text { my paper }\end{array}$ & $\begin{array}{l}\text { Sistem dapat } \\
\text { menampilkan daftar } \\
\text { paper }\end{array}$ & $\begin{array}{l}{[\sqrt{ }]} \\
\text { Berhasil } \\
{[] \text { Gagal }}\end{array}$ \\
\hline 69. & $\begin{array}{l}\text { Mengubah data } \\
\text { paper }\end{array}$ & $\begin{array}{l}\text { User memilih action } \\
\text { update paper, } \\
\text { kemudian } \\
\text { melakukan } \\
\text { perubahan data } \\
\text { paper, dan memilih } \\
\text { button save }\end{array}$ & $\begin{array}{l}\text { Sistem dapat } \\
\text { menyimpan } \\
\text { perubahan data } \\
\text { paper dan } \\
\text { menampilkan daftar } \\
\text { paper }\end{array}$ & $\begin{array}{l}{[\sqrt{ }]} \\
\text { Berhasil } \\
\text { [] Gagal }\end{array}$ \\
\hline 70. & $\begin{array}{l}\text { Menghapus } \\
\text { data paper }\end{array}$ & $\begin{array}{l}\text { User memilih action } \\
\text { delete paper pada } \\
\text { data paper yang } \\
\text { akan dihapus }\end{array}$ & $\begin{array}{l}\text { Sistem dapat } \\
\text { menghapus data } \\
\text { paper dan } \\
\text { menampilkan daftar } \\
\text { paper }\end{array}$ & $\begin{array}{l}{[\sqrt{ }]} \\
\text { Berhasil } \\
{[] \text { Gagal }}\end{array}$ \\
\hline 71. & $\begin{array}{l}\text { Menambah } \\
\text { data penulis }\end{array}$ & $\begin{array}{l}\text { User memilih action } \\
\text { tambah penulis, } \\
\text { kemudian mengisi } \\
\text { data penulis dan } \\
\text { memilih button save }\end{array}$ & $\begin{array}{l}\text { Sistem dapat } \\
\text { menyimpan data } \\
\text { penulis }\end{array}$ & $\begin{array}{l}{[\sqrt{ }]} \\
\text { Berhasil } \\
{[] \text { Gagal }}\end{array}$ \\
\hline 72. & $\begin{array}{l}\text { Menampilkan } \\
\text { detail data } \\
\text { penulis }\end{array}$ & $\begin{array}{l}\text { User memilih action } \\
\text { detail pada data } \\
\text { penulis yang akan } \\
\text { ditampilkan lebih } \\
\text { detail }\end{array}$ & $\begin{array}{l}\text { Sistem dapat } \\
\text { menampilkan detail } \\
\text { data penulis }\end{array}$ & $\begin{array}{l}{[\sqrt{ }]} \\
\text { Berhasil } \\
{[] \text { Gagal }}\end{array}$ \\
\hline 73. & $\begin{array}{l}\text { Mengubah data } \\
\text { penulis }\end{array}$ & $\begin{array}{l}\text { User memilih action } \\
\text { update pada data } \\
\text { penulis yang akan } \\
\text { diubah }\end{array}$ & $\begin{array}{l}\text { Sistem dapat } \\
\text { menyimpan } \\
\text { perubahan data } \\
\text { penulis }\end{array}$ & $\begin{array}{l}{[\sqrt{ }]} \\
\text { Berhasil } \\
{[] \text { Gagal }}\end{array}$ \\
\hline 74. & $\begin{array}{l}\text { Menghapus } \\
\text { data penulis }\end{array}$ & $\begin{array}{l}\text { User memilih action } \\
\text { delete pada data } \\
\text { penulis yang akan } \\
\text { dihapus }\end{array}$ & $\begin{array}{l}\text { Sistem dapat } \\
\text { menghapus data } \\
\text { penulis }\end{array}$ & $\begin{array}{l}{[\sqrt{ }]} \\
\text { Berhasil } \\
{[] \text { Gagal }}\end{array}$ \\
\hline 75. & $\begin{array}{l}\text { Melihat hasil } \\
\text { review paper }\end{array}$ & $\begin{array}{l}\text { User memilih button } \\
\text { lihat review }\end{array}$ & $\begin{array}{l}\text { Sistem dapat } \\
\text { menampilkan hasil } \\
\text { review sesuai paper } \\
\text { yang dipilih }\end{array}$ & $\begin{array}{l}{[\sqrt{ }]} \\
\text { Berhasil } \\
{[] \text { Gagal }}\end{array}$ \\
\hline 76. & $\begin{array}{l}\text { Mengubah } \\
\text { profil user }\end{array}$ & $\begin{array}{l}\text { User memilih menu } \\
\text { profil, kemudian } \\
\text { melakukan } \\
\text { perubahan data diri } \\
\text { user }\end{array}$ & $\begin{array}{l}\text { Sistem dapat } \\
\text { menyimpan } \\
\text { perubahan data diri } \\
\text { user }\end{array}$ & $\begin{array}{l}{[\sqrt{ }]} \\
\text { Berhasil } \\
{[] \text { Gagal }}\end{array}$ \\
\hline 77. & $\begin{array}{l}\text { Mengupload } \\
\text { bukti } \\
\text { pembayaran }\end{array}$ & $\begin{array}{l}\text { User memilih menu } \\
\text { pembayaran dan } \\
\text { mengupload bukti } \\
\text { pembayaran }\end{array}$ & $\begin{array}{l}\text { Sistem dapat } \\
\text { menyimpan bukti } \\
\text { pembayaran yang di } \\
\text { upload user }\end{array}$ & $\begin{array}{l}{[\sqrt{ }]} \\
\text { Berhasil } \\
{[] \text { Gagal }}\end{array}$ \\
\hline
\end{tabular}

\section{KESIMPULAN}

Kesimpulan yang diperoleh adalah system website CMS Conference telah berhasil dibuat dengan tidak ditemukannya syntax error maupun logic error pada kebutuhan fungsional. CMS Conference yang dibuat memiliki fitur utama yaitu manajemen tampilan conference, manajemen 
penerimaan artikel, manajemen proses reviewer, menejemen proses penerimaan artikel dan manajemen pembayaran. Adapun hal yang dapat dikembangkan kedepan dari system ini adalah dengan menambahkan proses pembayaran secara online misalkan pembayaran menggunakan debet, pay pall dan pembayaran online yang lainnya.

\section{UCAPAN TERIMA KASIH}

Kami ucapkan terimakasih pada semua pihak yang mendukung penelitian ini yaitu semua keluarga Fakultas MIPA Universitas Sebelas Maret terutama Program Studi D3 Teknik Informatika.

\section{DAFTAR PUSTAKA}

[1] O.-S. Loizides and P. Koutsakis, "On evaluating the quality of a computer science/computer engineering conference," Journal of Informetrics, 2017.

[2] A. Simon-Maeda, "A corpus-based study of the AAAL conference handbook," Journal of English for Academic Purposes, 2016.

[3] S. J. Reinartz and D. Urban, "Finance conference quality and publication success: A conference ranking," Journal of Empirical Finance, 2017.

[4] N. K. Dimitrios, D. P. Sakas and D. S. Vlachosa, "Modeling Publications in Academic Conferences," in ICININFO, 2014.

[5] M. Singh, T. Chakraborty, A. Mukherjee and P. Goyal, "Is this conference a top-tier? ConfAssist: An assistive conflict resolution framework for conference categorization," Journal of Informetrics, 2016.

[6] M. Deveugele and J. Silverman, "Peer-review for selection of oral presentations for conferences: Are we reliable?," Patient Education and Counseling, 2017.

[7] A. M. Morrison, Marketing and Managing Tourism Destinations, Abingdon: Routledge, 2013.

[8] J. Hermawan, Analisa-Desain dan Pemrograman Berorientasi Obyek dengan UML dan Visual Basic.Net, Yogyakarta: Andi, 2004.

[9] Anonimous, Shortcourse PHP Programming, Yogyakarta: Andi, 2009.

[10] B. Raharjo, Belajar Otodidak Framework Codelgniter Teknik Pemrograman Web dengan PHP dan Framework Codelgniter 3, Bandung: Informatika, 2015.

[11] A. S. and M. Shalahuddin, Rekayasa Perangkat Lunak (Terstruktur dan Berorientasi Objek), Bandung: Informatika, 2016. 